\title{
Erratum to: De novo generation of plant centromeres at tandem repeats
}

\author{
Chee How Teo • Inna Lermontova • Andreas Houben • \\ Michael Florian Mette $\cdot$ Ingo Schubert
}

Published online: 14 April 2013

(C) Springer-Verlag Berlin Heidelberg 2013

\section{Erratum to: Chromosoma}

\section{DOI 10.1007/s00412-013-0406-0}

The Table 1 of the original publication unfortunately contains error. The corrected Table is shown below:

Table 1 Range of GFP signals in living primary transformants

\begin{tabular}{|c|c|c|c|c|c|c|}
\hline & \multicolumn{3}{|l|}{ EL702C } & \multicolumn{3}{|l|}{ Col-0 } \\
\hline & \multirow[t]{2}{*}{ Number of plants analyzed } & \multicolumn{2}{|c|}{ Number of GFP spots } & \multirow[t]{2}{*}{ Number of plants analyzed } & \multicolumn{2}{|c|}{ Number of GFP spots } \\
\hline & & $\mathrm{CEN}^{\mathrm{d}}$ & Non-CEN & & $\mathrm{CEN}^{\mathrm{d}}$ & Non-CEN \\
\hline pcenH3 & $11^{\mathrm{a}}$ & 8 to 12 & na & $6^{\mathrm{a}}$ & 8 to 12 & na \\
\hline $\mathrm{pN}-\mathrm{cenH} 3$ & $11^{\mathrm{b}}$ & 8 to 12 & 1 to 4 & 6 & 8 to 12 & 0 \\
\hline pMIS12-N-cenH3 & $5^{\mathrm{b}}$ & 8 to 12 & 1 to 4 & $15^{\mathrm{c}}$ & na & 0 \\
\hline pC-CENPC-N-cenH3 & $6^{\mathrm{b}}$ & 8 to 12 & 1 to 4 & 10 & 8 to 12 & 0 \\
\hline
\end{tabular}

na not quantifiable due to nucleoplasmic GFP signals, CEN centromeric

${ }^{\text {a }}$ Strong nucleoplasmic GFP signals in addition to centromere spots

${ }^{\mathrm{b}}$ Strong centromeric and one to four smaller GFP spots

${ }^{\mathrm{c}}$ Very weak nucleoplasmic GFP signals and no presumed centromere spots

${ }^{\mathrm{d}}$ More than 10 centromeric signals appear rarely when sister centromere cohesion is leaky

The online version of the original article can be found at http:// dx.doi.org/10.1007/s00412-013-0406-0.

C. H. Teo • I. Lermontova • A. Houben • M. F. Mette •

I. Schubert $(\square)$

Leibniz Institute of Plant Genetics and Crop Plant Research (IPK),

Corrensstrasse 3, 06466 Gatersleben, Germany

e-mail: schubert@ipk-gatersleben.de

Present Address:

C. H. Teo

Agro-Biotechnology Institute, Malaysia (ABI), Ministry of

Science, Technology and Innovation, c/o MARDI Headquarters,

43400, Serdang, Selangor, Malaysia 